\title{
Assessing the Contribution of Vision 2020 Umurenge Programme on Poverty Reduction in Kigabiro Sector, Rwanda.
}

\author{
Rwakibibi Pascal \\ Master's Degree of Business Administration at University of Kigali \\ Postgraduate Studies
}

\begin{abstract}
The study aimed at assessing the contribution of VUP in poverty reduction especially in Kigabiro sector. This study has general objective which is to assess the contribution of Vision 2020 Umurenge programme on poverty reduction supported by three specific objectives which are to assess the contribution of public works on poverty reduction, to determine the contribution of financial services on poverty reduction, and also to evaluate the contribution of direct support services on poverty reduction especially in Kigabiro sector located in Rwamagana district, Eastern province. Internationally, poverty can describe different things in different part of the world to different people, but it can be defined as when people are not able to afford basic needs. USA has come a long way in addressing the problem, but progress seems to have slowed despite the recent years of economic recovery. In Africa, hundred millions of people in the poorer countries are worries only with survival and elementary needs and average poverty rate for sub-Saharan Africa stands at about 41 percent, and of the world's 28 poorest countries, 27 are in sub-Saharan Africa all with a poverty rate above 30 percent. Referring to Rwanda, because may people in Rwanda live in rural area, they also live-in poverty line which is so hard for GoR to answer each Rwandan's problem but poverty alleviation program has been established in order to reduce gap of lower bad living condition of Rwandans due to genocide took place in 1994 against Tutsi. In 1994 the poverty rate was 78\%, in year of 2000 poverty rate was $60.4 \%, 2011$ poverty rate was $44.9 \% .2014$ poverty rate was $39.1 \%$ and in 2020 poverty rate was $20 \%$. So, even if the poverty rate mentioned above are decreasing, poverty rate of $20 \%$ in 2020 is still high meaning that many people are in the poverty which is the main problem in this studies.
\end{abstract}

\section{Introduction}

Internationally, in the world poverty mean various things in different parts and also to the different people, that why Poverty can be defined as a state or condition in which a person or community lacks the financial resources and essentials for a minimum standard of living. In the United States poverty has come an extended way in addressing the problem, nevertheless improvement seems to have slowed despite the recent years of monetary or economic retrieval (economic recovery). Most people, in one way or another, are familiar with poverty or the concept of poverty (Michael, 2018). From the state's largely countless poor population to jobless Americans looking for job to low-wage service industry workers to single parents working multiple jobs, and also for millions of Americans, poverty is a daily fight or struggle that regularly results in deprivation and needs sacrifice.

United States also was built on the policy that financial status is the result of personal worth, and also religious teachings inspire helping the poor and the work of reducing poverty became merged into the materials of U.S. society. The problem has even increased in different may ways. Continuing to U.S, economic has added or creating many jobs since the downturn or decline ended, many of the jobs generated are not the same as job that were lost. In many areas, the problem of poverty has worsened during the recovery (Schwartz, 2005). 
Poverty is possibly the most persistent of problem, with consequences that can span a time, which can be moved across groups, and loom in the minds of personalities and families who living at the edge of poverty.

In Africa, the dare of poverty reduction in Africa is of a different order from that elsewhere and will involve different approaches (Collier, 2013). According to Brandt (1980), stated that poorest countries a hundred of millions of people are preoccupied solely with existence and fundamental needs like elementary needs. For them work is not regularly available or, when it is, pay is low and circumstances often just tolerable. Therefore, poverty reduction in rural areas, and hunger in both rural and urban areas, will depend heavily on the supportable or sustainable development of community. However, different people are currently questioning about the concept of development for several reasons a realization that more isn't always great, or growing respect for reducing outside needs and lowering levels of consumption (Bugingo, 2014). The process of community development takes charge of the situations and factors that influence a community and variations the quality of life of its members' community. Development of Community seeks to increase or develop quality of life.

In Rwanda, Rwanda is characterized by a population traumatized by a campaign of genocide in 1994, which included not only mass killings, but also systematic rape and massive dislocation. The population of Rwanda not only faces health problems caused by the poverty, but also physical and mental diseases related to genocide trauma (Chen, 2012). And also, in Rwanda Refugees and returnee movements, along with internal migration and a government mandated relocation programme, led to the largest percentage of population in resettlement in new communities but some of the displaced people did not have proper shelter, and required re-housing.

The national statistics of Rwanda report shows that poverty is at $39.1 \%$ as of $2013 / 14$, down from $44.9 \%$ as was reported in $2010 / 11$. During the same period, extreme poverty dropped from $24.1 \%$ to $16.3 \%$ (NISR, 2015).

Reviewing the Rwanda's poverty reduction strategy paper clearly shows that poverty in Rwanda is deeply rooted in the upheavals that have characterized the country ever since ethnic ideologies were entrenched in the early 1950s. even if the may agents in Rwanda are involved in poverty reduction such as government, NGOs (non-government organization) and also private sector (Cain, 2012). However, the tests are left to the researchers to find out whether the contributions of various factors in poverty reduction are taking a good progress or not. In general, development in Rwanda for eradicating poverty is guided under Vision 2020 a framework for Rwanda's development, presenting the key priorities and providing Rwandans with a guiding tool for the future as economic development and poverty reduction strategy (EDPRS) that seeks to address constraints towards achieving the Millennium Development Goals (MDGs) and the country's Vision 2020. It builds on achievements in human capital development and promotes three inter-dependent flagship development programme: Sustainable Growth for Jobs and Exports; Vision 2020 Umurenge (VUP); and Governance (Bugingo, 2014).

So, Vision 2020 Umurenge Program is the government strategy which help pro-poor to growth which aims at eradicating extreme poverty in the year of 2020. Its fundamental standard used to release productive capacities of the poor and extremely poor in order to lift them out of extreme poverty in a cost-effective and sustainable manner which lead them to be developed economically. In this regard, the Vision 2020 Umurenge Programme has been implemented in Kigabiro Sector of Rwamagana District in eastern province to improve living conditions of the population and ensure fast and harmonious development within the community. So, the study focused on assessing the contribution of VUP in poverty reduction by taking Kigabiro sector as case study.

\section{Literature}


According to Irobi (2012), studied on government programs and poverty reduction in Nigeria, the study employed questionnaire in data collection and found that government programs involvement has a positive impact on poverty reduction among the rural citizens. Remarkably, this study found that may urban citizens in this association experienced income generation increase their welfare and therefore, improved their economic status, political and social conditions after receiving the government support from government programs which used to reduce poverty. The findings shown that there is a significant difference between those people who are beneficiaries of government support and before of being beneficiaries of government programs (Leer, 2004). There is a significant effect of government program especially poverty reduction strategies in alleviating poverty by increasing income and changing economic status of those who support them. The study concludes that government program especially poverty reduction strategies is indeed a potent strategy of poverty reduction and a viable tool for providing financial services to the poor.

According to the study conducted by Austin and Leer (2004), it revealed that low-income families face significant barriers to using public and private services and to increasing earnings from work. Many lowincome families who would otherwise be eligible for government cash or in-kind assistance either do not know they are eligible, or find that the application process is an obstacle to receiving assistance (Yunus, 2012). In a study by Ayako (2006) on Lessons of the Experience with Direct Support to Schools Mechanism: the findings show that the Direct Support to Schools mechanism, designed to facilitate provision of Universal Primary Education (UPE), had been generally well received and had achieved positive outcomes such as improved access to primary education with enrolment rates increasing rapidly. The study identified key elements of successful implementation of the Direct Support to School (DSS) mechanism including: (i) involvement of multiple stakeholders, business, cultural institutions, students and marginalized groups. In addition, it concluded that effective literacy programs may have to accompany capacity building for local communities.

The Government of Tanzania, in 1991 initiated financial sector reforms in order to generate an efficient and effective financial system referring to the former governor of the Bank of Tanzania (Winch, 1987). The principal basics of the financial sector reform included liberalization of interest rates, removal of administrative credit and foreign exchange allocation, establishment of the Bank of Tanzania 's role in regulating and supervising financial institutions, reform of state-owned financial institutions, and allowing entry of private banks both local and foreign.

Despite of the proliferation of banking institutions and the wide range of banking products and services, it seems very little attention has been paid to help SMEs'capital enhancement and growth. However, the evidence showed the formal financial institutions find it difficult to deal with SMEs because of the lack of collateral, high incidence of defaults and high transactions costs associated with issuing of small credits (Yunus, 2012). Due to this, small businesses face a daunting obstacle whereby only few have access to regulated banks, savings and loan associations, investment funds. The level of provision of financial services to the small business sector and other sectors largely depends on the state of the financial system. Existing evidence suggests that despite the financial sector in Tanzania undergoing various development phases, growing small businesses are still constrained in terms of credit accessibility (Sraffa, 1926).

\section{Empirical review}

According to Irobi (2012), studied on government programs and poverty reduction in Nigeria, the study employed questionnaire in data collection and found that government programs involvement has a positive impact on poverty reduction among the rural citizens. Remarkably, this study found that may urban citizens in this association experienced income generation increase their welfare and therefore, improved their economic status, political and social conditions after receiving the government support from government programs which used to reduce poverty. The findings shown that there is a significant difference between those people who are beneficiaries of government support and before of being beneficiaries of government programs (Leer, 2004). There is a significant effect of government program especially poverty reduction 
strategies in alleviating poverty by increasing income and changing economic status of those who support them. The study concludes that government program especially poverty reduction strategies is indeed a potent strategy of poverty reduction and a viable tool for providing financial services to the poor.

According to the study conducted by Austin and Leer (2004), it revealed that low-income families face significant barriers to using public and private services and to increasing earnings from work. Many lowincome families who would otherwise be eligible for government cash or in-kind assistance either do not know they are eligible, or find that the application process is an obstacle to receiving assistance (Yunus, 2012). In a study by Ayako (2006) on Lessons of the Experience with Direct Support to Schools Mechanism: the findings show that the Direct Support to Schools mechanism, designed to facilitate provision of Universal Primary Education (UPE), had been generally well received and had achieved positive outcomes such as improved access to primary education with enrolment rates increasing rapidly. The study identified key elements of successful implementation of the Direct Support to School (DSS) mechanism including: (i) involvement of multiple stakeholders, business, cultural institutions, students and marginalized groups. In addition, it concluded that effective literacy programs may have to accompany capacity building for local communities.

The Government of Tanzania, in 1991 initiated financial sector reforms in order to generate an efficient and effective financial system referring to the former governor of the Bank of Tanzania (Winch, 1987). The principal basics of the financial sector reform included liberalization of interest rates, removal of administrative credit and foreign exchange allocation, establishment of the Bank of Tanzania 's role in regulating and supervising financial institutions, reform of state-owned financial institutions, and allowing entry of private banks both local and foreign.

Despite of the proliferation of banking institutions and the wide range of banking products and services, it seems very little attention has been paid to help SMEs'capital enhancement and growth. However, the evidence showed the formal financial institutions find it difficult to deal with SMEs because of the lack of collateral, high incidence of defaults and high transactions costs associated with issuing of small credits (Yunus, 2012). Due to this, small businesses face a daunting obstacle whereby only few have access to regulated banks, savings and loan associations, investment funds. The level of provision of financial services to the small business sector and other sectors largely depends on the state of the financial system. Existing evidence suggests that despite the financial sector in Tanzania undergoing various development phases, growing small businesses are still constrained in terms of credit accessibility (Sraffa, 1926).

However, information asymmetries associated with lending to small scale borrowers have still restricted SMEs to access financial loans (Ayako, 2006). For creating conducive business environment, the Government of the United Republic of Tanzania took initiatives to rearrange major banks and financial institutions in 1996, which included the restructuring and downsizing the National Bank of Commerce and the recapitalization of the Cooperative and Rural Development Bank through selling of shares to the general public as well as introduction of new local and foreign banks in which competition has been enhanced, resulting into improvement of quality and quantity of financial services they are offering.

The government has also established the National Microfinance Policy of 2000, the Cooperative Societies Act of 2003 and its regulations of 2004 and the National Economic Empowerment Policy and ACT of 2004. All these initiatives were meant to accelerate economic growth and assist the private sector to become key player in nurturing the entrepreneurship and enterprise development. Levine (2014), combining case studies with a sample survey of businesses that gained access to credit from Tanzanian government financial sources. The findings reveal that the enterprises whose owners received business training and extension advice perform better than those that did not.

The further study shows that many of the problems faced by the entrepreneurs are not related to capital, but rather arise as a result of macroeconomic and institutional constraints. Studies like one by Harvey and Reed 
(1992), have investigated the role of the institutions in promoting SMEs, but do not explain why the institutional framework for the promotion of SMEs is poorly integrated or what constraints the SMEs support institutions themselves face. The quality of the institutional framework depends on the capacity of the players within it. It turns out therefore to be important to conduct a critical assessment of the capacity of the existing SMEs support institutions so as to understand the factors underlying the dismal performance of the institutional framework for SMEs development.

\section{Methodology}

According to Gravether (2013), research design is defined as the deliberately planned arrangement of conditions for the analysis and collection of data in a manner that aims to combine relevance to research purpose with economy of procedure or are plans that guide decisions about when and how often to collect data, and what data to gather, from whom and how to collect data, and to analyze data. This study will use a survey research design. The study mainly will use survey design which allowed researcher to integrate in Kigabiro sector through primary data and processed through descriptive (frequency, percentage) and inferential (multiple regression).

This research also adopts both descriptive and correlation research design. It is descriptive because describes the contribution of VUP on poverty reduction by using frequencies and percentages. It is correlation research because shows the relationship between supplier VUP and poverty reduction by using Pearson correlation, multiple regression also used to determine the contribution of VUP components to sub variable of poverty reduction and verification of hypothesis by showing model summary, ANOVA, and coefficient.

According to Gravether (2013), define a population as a set of individuals or objects with the same characteristics. And also Gravether stated that population has two types which are known population (when it is well defined) and unknown (when it is not well defined) population. The target population in this study is 269 respondents who are VUP beneficiaries of Kigabiro sector which has five cells: Nyagasenyi, Sibagire, Sovu, Cyanya, and Bwiza. All this constitutes the population with the potential to provide valid information about the contribution of VUP on poverty reduction.

\section{Findings, Discussion and Interpretation}

The first objective was to assess the contribution of public works on poverty reduction in Kigabiro sector. After the analysis and interpretation of the data; the research revealed that various questions were asked to see if public works service contribute to poverty reduction in Kigabiro sector, the result indicated that 52.3\% respondents had strongly agreed that in Kigabiro sector, no bias in choosing VUP beneficiary because only extremely poor classified in Ubudehe 1 and 2 and who are able to work are those who make public works. $77.8 \%$ respondents were strongly agreed that VUP beneficiaries in Kigabiro sector always intend to build productive community assets by supporting land conservation $74.1 \%$ respondents were strongly agreed that Kigabiro sector, VUP beneficiaries' community work services intend to maintain physical infrastructure or supporting agriculture livelihood. Simply, for public work service many respondents were strongly agreed on its statements.

The second objective of this study was to determine the contribution of support services on poverty reduction in Kigabiro sector. Following the question that was asked by the researcher in order to understand about the contribution of support services on poverty reduction. The result indicate that many respondents of $55.6 \%$ of respondents were strongly agreed that Kigabiro sector, VUP beneficiaries assess social services or get land household with no members qualifying for public works or credit package, $51.9 \%$ agreed that Kigabiro sector, VUP help its beneficiaries to expand health in Kigabiro sector, and lastly 53.7\% were strongly disagreed on the statement says that VUP in Kigabiro sector, helped the beneficiaries to develop their education coverage as well as appropriate skills, handcraft. Briefly, these results from the question 
related to the direct support service, shows that even many people strongly agreed and agreed on the two first statement some of them strongly disagreed third statement.

Regarding to the third objective of this research which was to evaluate the contribution of support services on poverty reduction in Kigabiro sector. The results indicate that many respondents of $50.0 \%$ of respondents were strongly disagreed that after being VUP beneficiary in Kigabiro sector, they increase their saving account, $50.0 \%$ of respondents were strongly disagreed that they have the act of developing a habit of saving because they have earned much money from their business due to the financing services they have received from VUP, and lastly $48.1 \%$ respondents were strongly agreed that they are willing to make saving money on regular basis because they develop consistent saving habit in their life.

\section{Conclusion and Recommendation}

Based on the result from table 4.8 of support service indicates that $53.7 \%$ were strongly disagreed on this statement, $31.5 \%$ were disagreed for the third statement which says that VUP in Kigabiro sector, helped the beneficiaries to develop their education coverage as well as appropriate skills, handcraft. Therefore, the researcher based on these would like to recommend to the leader of Kigabiro to mobilize and encourage their VUP beneficiaries to develop their education and handcraft which lead them to reduce their poverty.

According to the results from table 4.9 of financial service, indicate that $51.9 \%$ were strongly disagreed, and $33.3 \%$ were disagreed that through the credits they get through VUP they improve their own productive capacity, on this scenario researcher recommend to the management of VUP in Kigabiro to educate VUP beneficiaries to use and request credit that is allowed to get on the activities which generate income in order to improve their own productive capacity. For the third statement of this table 4.9 indicate that $44.4 \%$ were strongly disagreed, $24.1 \%$ were disagreed that after being a VUP beneficiary, their poverty was reduced due to the diversifying farming through credit package they got. Therefore, researcher recommend to the management of VUP in Kigabiro sector to train and educate the VUP beneficiaries to use the opportunity they got through VUP program in order to spreading their activities including farming.

According to the result from table 4.10 improve lifestyle, shows that $33.3 \%$ of respondents were strongly disagreed, $40.7 \%$ of respondents were disagreed that their families assess basic needs because of services they got from Vision 2020 Umurenge program in Kigabiro sector. For the second statement $44.4 \%$ of respondents were strongly disagreed, $33.3 \%$ of respondents were disagreed that after being VUP's beneficiary their families have good welfare because of regularly health credit packages they got through direct support service of VUP in Kigabiro sector. here researcher recommend to the management of VUP beneficiaries in Kigabiro to use well their wages they got from VUP program in order to afford their basic need like complete feeding, to pay health insurance on time, etc.

Based on the result from table 4.11 of income generation indicate that $59.3 \%$ of respondents were strongly disagreed, $29.6 \%$ of respondents were disagreed that Vision 2020 Umurenge program help them and encourage them to be financial empowerment in order to reduce their poverty. Researcher recommend to the management of VUP in Kigabiro to encourage the beneficiaries of VUP to be financial empowerment.

\section{References}

1. Adeyemi, K. (2012). Sustainable development strategies for poverty alleviation to the tax perspectives. In Annual tax conference of the chartered institute of taxation. Nicon Luxury Hotel.

2. AFI report. (2019), The role of social protection program in Rwanda

3. Albrecht, C. \& Milford, K. (2001). Poverty and its impact on Health: A Scan of research literature. Canadian institute for health information, Ottawa.

4. Ayako, L. (2006). Assessing the impact of microcredit on women empowerment: confusing the boundary between growth and capitalism. Journal of Banking and Finance, 2(4). 67-82.

5. Balkenhol, R. (2013). The impact of financial services on the poor: Revisiting the evidence. U.S.A, New York. 
6. Barringer, P. (2012). Rural credit programs and women's empowerment in U.S. World Development, 24(4), $635-653$.

7. Bugingo, E. (2014). Poverty alleviation and elimination in Rwanda $\left(2^{\text {nd }}\right.$, Ed.). Butare: Rwanda Ministry of Education.

8. Cain, H. (2012). Impacts of income-generating programme in micro-enterprise and children. Small Enterprise Development.

9. Cartwright, E. (2007). Accessing how micro-credit and continuousness of indebtedness dynamics in the rural area of Mexico. Rural Microfinance and Employment.

10. Chen, S. (2012). The developing world is poorer than we thought but no less successful in the fight against poverty (Policy Research Working Paper WPS4703).

11. Collier, D. (2013). Finance services against poverty. Journal of International Development, 10(6), 837-839.

12. Rasa, S. (2014). Assessment of social-economic and its impact on encouragements of individual taxation. Journal of Security and Sustainability Issues, 4(1), 79-95.

13. Fontinelle, G. (2015). Anatomy of government strategy on poverty reduction. The Journal of International Development, 1(5), 201-213.

14. Gordon, D. (1982). Book review: role of finance services against poverty. Journal of International Development, 10(6), 837-839.

15. Gravether, H. (2013). Statistical analysis: lessons and proposals. Development in Practice.

16. Hall, B. \& Jones, H. (1999). Theoretical review of market-oriented strategy for small and medium scale enterprises. International Finance Corporation Discussion Paper, 2(1),40-45.

17. Harvey, N. \& Reed, F. (1992). Microfinance and poverty alleviation with its related theory, a case study of Uganda finance trust. Development policy review.

18. Irobi, I. (2012). Poverty reduction in sub-Saharan Africa: Is there a role for the private sector? African Development Bank.

19. Keating, R. (2012). Financing small and medium enterprise growth on poverty decline in developing countries. Journal of International Development, 12(8). 79-83.

20. Kirubi, P. (2013). Microfinance, social capital formation political development in Russia and eastern Europe: a pilot study of programs in Russia, Slovakia and Romania

21. Leer, S. (2004). Capital distribution and industry development. Journal of Financial Economics, 6(4),39-48.

22. Levine, O. (2014). Contribution of microfinance on women's empowerment: a lesson from India. Development in Practice.

23. Levy, J. (2013). Research method and statistical analysis: evidence from the Grameen Bank. Journal of Development Economics, 1(2), 12-15.

24. Mauri, K. (2011). Microfinance on rural and urban transformation of Rwanda: Practices and policy environment in Rwanda.

25. Michael, E. (2018). Implication of developing country on reducing poverty in rural area. Washington D.C.: International Monetary Fund.

26. Mosley, R. (2012). Financial performance and outreach: a global analysis of leading micro banks. Economic Journal, 3(5), 50-53.

27. Mpayimana, E. (2016). Vision 2020 Umurenge program and poverty reduction in Nyarubaka sector, Rwanda. UR, College of business and economics school of business.

28. NISR. (2015). Integrated household living conditions survey $\left(4^{\text {th }}, E d\right.$.), Social protection and VUP report. Kigali, Rwanda. 
29. Okibo, J. \& Makanga, I. (2014). Surveying the relationship between good governance and social responsibility in ardabil municipality. The journal of Singaporean of Business Economics and Management Studies, 3(3), 124-132

30. Oscar, L. (1968). The theory of poverty eradication: A Case study in Mogadishu. International Journal of Humanities, Social sciences and Education, 2(2), 56-62.

31. Pamela, M. (2013). Microfinance, and savings: lessons and proposals. Development in Practice.

32. Robert, S. (1956). The poor always pay back. Plumarian Press: Bloomfield, CT.

33. Ronald, R. (2011). Wider impacts of microfinance institutions: issues and concepts and theories. The Journal of International Development, 16 (3), 301-330. 